\title{
Genetic Variation in Blood Pressure and Lifetime Risk of Peripheral Artery Disease: A Mendelian Randomization Study
}

Michael G. Levin, MD ${ }^{1,2,3}$; Derek Klarin, MD ${ }^{4,5}$; Venexia M. Walker, $\mathrm{PhD}^{6}$; Dipender Gill, BMBCh, $\mathrm{PhD}^{7,8,9,10,11}$; Julie Lynch, PhD ${ }^{12,13}$; Kyung M. Lee, $\mathrm{PhD}^{13,14,15}$; Themistocles L. Assimes, MD, PhD 16,17,18; Pradeep Natarajan, MD 19,20,21,22; Adriana M. Hung, MD ${ }^{23}$; Todd Edwards, PhD ${ }^{24}$; Daniel J. Rader, MD2,25,26; J. Michael Gaziano, MD, MPH 22,27; Neil M. Davies, PhD ${ }^{6}$; Philip S. Tsao, 8 PhD ${ }^{16,28}$; Kyong-Mi Chang, MD ${ }^{2,3}$; Benjamin F. Voight, PhD 3,25,26,29; Scott M. Damrauer, MD ${ }^{3,30}$; 9 on behalf of the VA Million Veteran Program

\section{Corresponding Author:}

363900 Woodland Avenue

37 Philadelphia PA 19104

38 Phone: 215-823-5880

39 scott.damrauer@va.gov

40 damrauer@upenn.edu

43 Key Words: Blood pressure; Genetics; Atherosclerosis; Peripheral Artery Disease 
${ }^{1}$ Division of Cardiovascular Medicine, University of Pennsylvania Perelman School of Medicine, Philadelphia, PA 
medRxiv preprint doi: https://doi.org/10.1101/2020.08.23.20180240; this version posted August 25, 2020. The copyright holder for this preprint (which was not certified by peer review) is the author/funder, who has granted medRxiv a license to display the preprint in perpetuity.

It is made available under a CC-BY-NC-ND 4.0 International license .

ABSTRACT:

Aims: We aimed to estimate the effect of blood pressure and blood pressure lowering medications (via genetic proxies) on peripheral artery disease.

Methods and Results: GWAS summary statistics were obtained for BP (International

93 Consortium for Blood Pressure + UK Biobank GWAS; $\mathrm{N}=$ up to 757,601 individuals), peripheral

94 artery disease (PAD; VA Million Veteran Program; $N=24,009$ cases, 150,983 controls), and

95 coronary artery disease (CAD; CARDIoGRAMplusC4D 1000 Genomes; N = 60,801 cases, 123,504

97 and CAD and PAD were estimated using LD score regression. The strongest correlation was

98 between SBP and CAD $\left(r_{g}=0.36 ; p=3.9 \times 10^{-18}\right)$. Causal effects were estimated by two-sample

99 MR using a range of pleiotropy-robust methods. Increased SBP, DBP, and PP increased risk of

100 both PAD (SBP OR 1.25 [1.19-1.31] per 10mmHg increase, $p=3 \times 10^{-18}$; DBP OR 1.27 [1.17-1.39], $p=4 \times 10^{-8} ;$ PP OR $\left.1.51[1.38-1.64], p=1 \times 10^{-20}\right)$ and CAD (SBP OR 1.37 [1.29-1.45], $p=2 \times 10^{-24}$ DBP were greater for CAD than PAD ( $p_{\text {diff }}=0.024$ for SBP, $p_{\text {diff }}=4.9 \times 10^{-4}$ for DBP). Increased

104 liability to PAD increased PP (beta $=1.04[0.62-1.45] \mathrm{mmHg}$ per 1 unit increase in log-odds in 105 liability to $\left.P A D, p=1 \times 10^{-6}\right)$. MR was also used to estimate the effect of BP lowering through 106 different classes of antihypertensive medications using genetic instruments containing BP-trait 107 associated variants located within genes encoding protein targets of each medication. SBP 108 lowering via calcium channel blocker-associated variants was protective of CAD (OR 0.38 per 109 10mmHg decrease in SBP; 95\% Cl 0.19-0.77; $p=0.007)$. 
medRxiv preprint doi: https://doi.org/10.1101/2020.08.23.20180240; this version posted August 25, 2020. The copyright holder for this preprint (which was not certified by peer review) is the author/funder, who has granted medRxiv a license to display the preprint in perpetuity. It is made available under a CC-BY-NC-ND 4.0 International license.

110 Conclusions: Higher BP is likely to cause both PAD and CAD but may have a larger effect on CAD

111 risk. BP-lowering through calcium-channel blockers (as proxied by genetic variants) decreased

112 risk of CAD.

113 
medRxiv preprint doi: https://doi.org/10.1101/2020.08.23.20180240; this version posted August 25, 2020. The copyright holder for this preprint (which was not certified by peer review) is the author/funder, who has granted medRxiv a license to display the preprint in perpetuity.

It is made available under a CC-BY-NC-ND 4.0 International license .

\section{INTRODUCTION:}

115 Peripheral artery disease (PAD) is a common manifestation of atherosclerotic

116 cardiovascular disease (ASCVD), estimated to affect more than 12 million individuals in the

117 United States, and more than 120 million individuals worldwide (1,2). PAD shares a number of

118 risk factors with other forms ASCVD like coronary artery disease (CAD) and ischemic stroke (3).

119 These risk factors include smoking, diabetes, hypertension, hyperlipidemia, and obesity (2-4).

120 Observational studies have identified hypertension as one of the strongest risk factors for

121 incident and prevalent PAD (5-11), although these studies may be limited by residual

122 environmental confounding or reverse-causality. While randomized controlled trials of

123 antihypertensive medications have demonstrated broad protection from coronary artery

124 disease and death from cardiovascular causes, whether lower blood pressure reduces risk of

125 PAD specifically has not been reliably established. Similarly, the relative effect of blood pressure 126 on PAD and CAD has not been fully investigated.

127 Recent genome-wide association studies (GWAS) of PAD, CAD, and blood pressure

128 including more than 700,000 individuals have identified hundreds of genetic variants associated

129 with these traits $(12,13)$. The Mendelian randomization (MR) framework (under certain

130 assumptions) can leverage this genetic variation (which is randomly assorted during meiosis,

131 mimicking a randomized trial), to provide unconfounded causal estimates of the relationship

132 between traits (14). MR assumes that genetic variants are likely to be independent of many

133 confounders of the exposure-outcome relationship. This assumption is plausible because

134 genetic variants are randomly inherited by offspring from parents during meiosis and

135 conception, analogous to treatment allocation in a randomized trial. Because large randomized 
medRxiv preprint doi: https://doi.org/10.1101/2020.08.23.20180240; this version posted August 25, 2020. The copyright holder for this preprint (which was not certified by peer review) is the author/funder, who has granted medRxiv a license to display the preprint in perpetuity.

It is made available under a CC-BY-NC-ND 4.0 International license .

136 trials evaluating the relationship between treatment of hypertension and PAD outcomes may

137 be unfeasible, other study designs are needed to fill this evidence gap. Here, we leverage

138 population-scale genetic variation within the Mendelian randomization framework to 1)

139 establish the relationship between blood pressure and risk of PAD, 2) quantify differences in

140 the effect of blood pressure on CAD and PAD, and 3) estimate the effect of blood pressure

141 lowering (using genetic proxies of antihypertensive medications) on PAD risk.

143 METHODS:

144 Study Exposures

145 The 2018 Evangelou et al. International Consortium for Blood Pressure + UK Biobank GWAS,

146 which included measurements of systolic blood pressure, diastolic blood pressure, and pulse

147 pressure in up to 757,601 individuals was used to identify genetic variants associated with the

148 primary blood pressure phenotypes (15). This study included up to 299,024 European

149 participants from 77 independent studies genotyped with various arrays and imputed to either

150 the 1000 Genomes Reference Panel or the HRC panels, and 458,577 participants from the UK

151 Biobank imputed to UK10K + 1000 Genomes reference panel. Measurement of blood pressure

152 varied among cohorts, and study-specific details are presented in the supplemental material of

153 Evangelou et al., 2018. Summary statistics for the blood pressure genome wide association

154 study are publicly available, and may be downloaded from the NHLBI GRASP catalog

155 (https://grasp.nhlbi.nih.gov/FullResults.aspx). 
medRxiv preprint doi: https://doi.org/10.1101/2020.08.23.20180240; this version posted August 25, 2020. The copyright holder for this preprint (which was not certified by peer review) is the author/funder, who has granted medRxiv a license to display the preprint in perpetuity.

It is made available under a CC-BY-NC-ND 4.0 International license .

158 The 2019 Million Veteran Program genome wide association study of Peripheral Artery Disease

159 by Klarin et al. identified 24,009 cases and 150,983 controls of European Ancestry (12). This

160 study defined cases and controls based on electronic health record phenotyping within the

161 Veterans Affairs (VA) Healthcare System and was validated against ankle brachial index

162 measurement and manual chart review. The current analysis focused on participants of

163 European ancestry. MVP PAD genome wide association study summary statistics are available

164 on dbGAP (Accession phs001672.v2.p1).

165

166 Genome-wide association study summary statistics for coronary artery disease were obtained

167 from the Nikpay et al. 2016 CARDIoGRAMplusC4D 1000 Genomes-based GWAS. This study was

168 a meta-analysis including 60,801 CAD cases and 123,504 controls, with genotypes imputed

169 using the 1000 Genomes phase 1 version 3 reference. Summary statistics were downloaded

170 from www.cardiogramplusc4d.org/data-downloads/.

171

\section{Genetic Correlation}

173 LD-score regression was used to estimate the genetic correlation between blood pressure

174 traits, and between blood pressure traits and ASCVD traits (https://github.com/bulik/ldsc)

175 (16,17). GWAS summary statistics were obtained for systolic blood pressure, diastolic blood

176 pressure, pulse pressure, peripheral artery disease, and coronary artery disease $(12,13,15)$.

177 Summary statistics were filtered to HapMap3 SNPs, and SNP heritability and genetic

178 correlations were estimated using pre-computed 1000 Genomes European LD-scores. 
medRxiv preprint doi: https://doi.org/10.1101/2020.08.23.20180240; this version posted August 25, 2020. The copyright holder for this preprint (which was not certified by peer review) is the author/funder, who has granted medRxiv a license to display the preprint in perpetuity.

It is made available under a CC-BY-NC-ND 4.0 International license .

\section{Mendelian Randomization}

181 Two-sample Mendelian randomization analyses were performed in R using the TwoSampleMR 182 package (https://github.com/MRCIEU/TwoSampleMR) (18). Genetic instruments for SBP, DBP,

183 and PP were constructed using linkage-disequilibrium independent $\left(r^{2}<0.001\right.$, distance $=$

184 10,000kb; 1000 Genomes European reference panel), genome-wide significant $\left(p<5 \times 10^{-8}\right)$

185 variants identified using GWAS summary statistics for each trait (Supplemental Table 3). For bi-

186 directional MR analysis, additional instruments were constructed for CAD and PAD using the

187 same procedure (Supplemental Table 6). For each variant included in the genetic instruments,

188 proportion of variance explained was calculated using the formula $R^{2}=$

$\frac{2 \beta^{2} M A F(1-M A F)}{2 \beta^{2} M A F(1-M A F)+2 N M A F(1-M A F) s e^{2}}$ (where MAF represents the effect allele-frequency, beta

represents the effect estimate of the genetic variant in the exposure GWAS, se represents the

191 standard error of effect size for the genetic variant, and $\mathrm{N}$ represents the sample size)(19). F-

192 statistics were calculated for each variant using the formula $F=\frac{R^{2} \times(N-2)}{1-R^{2}}$ (where $\mathrm{R}^{2}$ represents

193 the variance in exposure explained by the genetic variant, and $\mathrm{N}$ represents the number of

194 individuals in the exposure GWAS) to assess the strength of the selected instruments

195 (Supplemental Table 4)(20). For the primary analysis, power calculation was performed to

196 identify the minimum-detectable effect size maintaining $80 \%$ power with two-sided alpha of

197 0.05. The primary MR analyses used inverse-variance weighting with random effects. The MR-

198 Egger intercept test was used to evaluate for evidence of horizontal pleiotropy. Leave-one-out,

199 single-SNP, and funnel-plot diagnostic MR analyses were performed. Sensitivity analyses were

200 performed using MR methods that make different assumptions about the presence of

201 pleiotropy (weighted median, penalized weighted median, and weighted mode) (21). 
medRxiv preprint doi: https://doi.org/10.1101/2020.08.23.20180240; this version posted August 25, 2020. The copyright holder for this preprint (which was not certified by peer review) is the author/funder, who has granted medRxiv a license to display the preprint in perpetuity.

It is made available under a CC-BY-NC-ND 4.0 International license .

202 Multivariable MR (MVMR) was used in additional sensitivity analyses to jointly estimate the

203 direct effects of multiple blood pressure traits, using genetic instruments including genomically

204 independent $\left(r^{2}<0.001\right.$, distance $\left.=10,000 \mathrm{~kb}\right)$ variants that were associated at genome-wide

205 significance $\left(p<5 \times 10^{-8}\right)$ with any exposure, weighted by the effect of each SNP on each

206 exposure (Supplemental Table 8)(22). Effect estimates were scaled to correspond to a $10 \mathrm{mmHg}$

207 change in blood pressure.

208

209 Antihypertensive Drug MR

210 Two MR analyses were performed to estimate the effect of $10 \mathrm{mmHg}$ lower of blood pressure

211 by antihypertensive drugs. In the first analysis, genetic instruments consisting of variants within

212 genes encoding protein targets of ACE-inhibitors, beta-blockers, and calcium-channel blockers

213 were obtained from Gill et. al., with each variant weighted by its effect on systolic blood

214 pressure (Supplemental Table 5)(23). In a sensitivity analysis, genetic instruments were

215 constructed that mimic the action of 12 antihypertensive medication classes. In contrast to the

216 first method which selected genetic variants based on their proximity to genes encoding

217 protein targets, this method prioritized variants representing expression quantitative trait loci

218 (eQTL) for genes encoding protein targets of antihypertensive medications that were

219 demonstrated to effect systolic blood pressure (24). For both methods, inverse-variance

220 weighted and weighted-median MR was performed, with MR-Egger intercept test used to

221 assess for horizontal pleiotropy. For instruments with only 1 variant, Wald-ratio MR was

222 performed. 
medRxiv preprint doi: https://doi.org/10.1101/2020.08.23.20180240; this version posted August 25, 2020. The copyright holder for this preprint (which was not certified by peer review) is the author/funder, who has granted medRxiv a license to display the preprint in perpetuity.

It is made available under a CC-BY-NC-ND 4.0 International license .

\section{Statistical Analysis}

225 All statistical analyses were performed using R version 3.6.2 (R Foundation for Statistical

226 Computing).

227

228 RESULTS:

229 Genetic Correlation

230 Cross-trait LD-score regression was used to estimate the genetic correlation between

231 blood pressure traits. All blood pressure traits (SBP, DBP, PP) were strongly, positively

232 correlated (Supplemental Figure 1; Supplemental Table 1). The strongest correlation among

233 blood pressure traits was between systolic blood pressure and pulse pressure $(\mathrm{rg}=0.85 ; \mathrm{p}<1.0$ $\left.234 \times 10^{-300}\right)$.

235 Genetic correlation between blood pressure traits and ASCVD traits (CAD and PAD) was

236 then assessed. All BP traits were strongly, positively correlated with ASCVD traits

237 (Supplemental Figure 2; Supplemental Table 2). The strongest correlation among BP and

238 ASCVD traits was between systolic blood pressure and CAD $\left(\mathrm{rg}=0.36 ; \mathrm{p}=3.9 \times 10^{-18}\right)$.

240 Effects of Blood Pressure on ASCVD: Mendelian Randomization

To determine whether the genetic correlations between BP and ASCVD traits would be

242 consistent with causal effects, we performed two-sample mendelian randomization using

243 genome-wide association study summary statistics. Genetic instruments for blood pressure

244 contained between 342 and 410 independent genetic variants, explaining between 3.5\% and

$2454.3 \%$ of the variability in blood pressure, with F-statistics ranging from 29.6 to 670.6 (consistent 
medRxiv preprint doi: https://doi.org/10.1101/2020.08.23.20180240; this version posted August 25, 2020. The copyright holder for this preprint (which was not certified by peer review) is the author/funder, who has granted medRxiv a license to display the preprint in perpetuity.

It is made available under a CC-BY-NC-ND 4.0 International license .

246 with low risk of weak-instrument bias) (Supplemental Tables 3-4). The primary analysis

247 maintained power to detect a $7 \%-11 \%$ increase in risk of ASCVD per $10 \mathrm{mmHg}$ increase in

248 blood pressure (Supplemental Table 4). In inverse-variance weighted analyses, each $10 \mathrm{mmHg}$

249 increase in SBP increased risk of both PAD (OR 1.25; 95\% Cl 1.19-1.31; $\mathrm{p}=3 \times 10^{-18}$ ) and CAD

250 (OR 1.37; 95\% Cl 1.29-1.45; $p=2 \times 10^{-24}$ ), though the effect was stronger for CAD than PAD

251 ( pdifference $\left._{\text {}}=0.024\right)$ (Figure 1, Supplemental Table 5). Each 10mmHg increase in DBP increased

252 risk of both PAD (OR 1.27; 95\% Cl 1.17-1.39; $\left.p=4 \times 10^{-8}\right)$ and CAD (OR 1.6; $95 \% \mathrm{Cl} 1.45-1.76 ; \mathrm{p}=$

$\left.2537 \times 10^{-22}\right)$, with a stronger effect for CAD than PAD $\left(p_{\text {difference }}=4.9 \times 10^{-4}\right)$ (Figure 1,

254 Supplemental Table 5). Each $10 \mathrm{mmHg}$ increase in PP increased risk of both PAD (OR 1.51; 95\%

$\left.255 \mathrm{Cl} 1.38-1.64 ; p=1 \times 10^{-20}\right)$ and CAD (OR 1.56; 95\% Cl 1.4-1.75; $p=1 \times 10^{-15}$ ), with similar effects

256 on CAD and PAD ( $p_{\text {difference }}=0.60$ ) (Figure 1, Supplemental Table 5). MR-Egger bias intercept

257 term was $p>0.05$ for all trait-outcome pairs except PP-PAD ( $p=0.012)$ (Supplemental Table 5).

258 Results remained robust in sensitivity analyses using MR methods that make different

259 assumptions about the presence of pleiotropy (Supplemental Table 5).

Effects of Liability to ASCVD on Blood Pressure: Mendelian Randomization

Because stiffening of peripheral vessels in the setting of peripheral artery disease may

263 affect blood pressure, raising the possibility of reverse-causation in assessment of the

264 relationship between blood pressure and PAD, bi-directional MR analysis was performed.

265 Genetic instruments for PAD and CAD were selected and used to estimate the effect of liability

266 to ASCVD on blood pressure traits (Figure 2; Supplemental Tables 6-7). In inverse-variance

267 weighted analysis, liability to PAD increased PP (beta $=0.97 \mathrm{mmHg}$ per 1 log-odds increase in 
medRxiv preprint doi: https://doi.org/10.1101/2020.08.23.20180240; this version posted August 25, 2020. The copyright holder for this preprint (which was not certified by peer review) is the author/funder, who has granted medRxiv a license to display the preprint in perpetuity.

It is made available under a CC-BY-NC-ND 4.0 International license .

risk of PAD; 95\% Cl 0.4-1.5; $\mathrm{p}=8 \times 10^{-4}$ ), and CAD increased PP (beta $=0.542$ per 1 log-odds

increase in risk of CAD; 95\% $\mathrm{Cl} 0.006-1.1 ; \mathrm{p}=0.05$. Neither PAD nor CAD affected SBP or DBP.

270 The MR-Egger bias intercept term had $p>0.05$ for all analyses, indicating no positive evidence

271 for bias. In sensitivity analysis applying MR methods making different assumptions about the

272 presence of pleiotropy, there was weak evidence that both PAD and CAD increase SBP and PP

273 while decreasing DBP (Supplemental Table 7).

274

275

\section{Multivariable Mendelian Randomization}

Because blood pressure traits are highly correlated and unlikely to affect cardiovascular

277 outcomes in isolation, we performed multivariable MR to jointly estimate the direct effects of

278 each blood pressure trait on ASCVD outcomes (Supplemental Table 8). Each 10mmHg increase

279 in SBP increased risk of both PAD (direct OR 1.67; 95\% Cl 1.19-2.34; $p=0.003$ ) and CAD (direct

280 OR 1.44; 95\% $\mathrm{Cl} 1.02-2.03 ; \mathrm{p}=0.04)$. After accounting for the effect of SBP, we did not observe

281 residual evidence of a significant direct effect of DBP on PAD or CAD.

283 Antihypertensive Drug Mendelian Randomization

Two Mendelian randomization analyses were performed to estimate the effect of blood

pressure lowering on ASCVD outcomes. The first analysis focused on the effect of SBP lowering

using genetic variants located within genes encoding protein targets of common classes of

287 blood pressure lowering medications (ACE-inhibitors, beta-blockers, and calcium channel

288 blockers) (Figure 3; Supplemental Tables 10-11). This analysis identified protective effects of

289 beta-blocker-associated variants on CAD (OR 0.59 per $10 \mathrm{mmHg}$ decrease in SBP; $95 \% \mathrm{Cl} 0.44-$ 
medRxiv preprint doi: https://doi.org/10.1101/2020.08.23.20180240; this version posted August 25, 2020. The copyright holder for this preprint (which was not certified by peer review) is the author/funder, who has granted medRxiv a license to display the preprint in perpetuity.

It is made available under a CC-BY-NC-ND 4.0 International license .

290 0.78; $p=3 \times 10^{-4}$ ), and protective effects of calcium channel blocker associated variants on CAD

291 (OR 0.69 per 10mmHg decrease in SBP; 95\% Cl 0.59-0.80; $p=2 \times 10^{-6}$ ). No effect of blood

292 pressure lowering via genetic proxies of these medication classes on risk of PAD was detected.

293 Results were consistent in weighted-median MR sensitivity analyses (Supplemental Table 11).

294 In the second analysis, the effects of both SBP and DBP lowering conferred by genetic

295 variants located within targets of a broader set of antihypertensive medications were

296 considered (Supplemental Tables 12-13). Results for SBP were similar to the first analysis,

297 identifying protective effects of calcium channel blocker associated variants on CAD (OR 0.64

298 per $10 \mathrm{mmHg}$ decrease in SBP; $\left.95 \% \mathrm{Cl} 0.50-0.81 ; \mathrm{p}=2 \times 10^{-4}\right)$, vasodilator associated variants on

299 CAD (OR 0.62 per $10 \mathrm{mmHg}$ decrease in SBP; $95 \% \mathrm{Cl} 0.40-0.95 ; \mathrm{p}=0.03$ ), and angiotensin II

300 receptor antagonist associated variants on CAD (OR 0.30 per $10 \mathrm{mmHg}$ decrease in SBP; $95 \% \mathrm{Cl}$

$301 \quad 0.097-0.95 ; p=0.04)$. Though not associated with CAD, SBP lowering via beta-blocker

302 associated variants decreased risk of PAD (OR 0.51 10mmHg decrease in SBP; 95\% $\mathrm{Cl}$ 0.27-0.97;

$303 p=0.04)$. Only results for calcium channel blocker associated variants were robust in weighted-

304 median sensitivity analyses.

$305 \quad$ For diastolic blood pressure, lowering via calcium channel blocker associated variants

306 decreased risk of CAD (OR 0.52 per 10mmHg decrease in DBP; 95\% Cl 0.34-0.78; $p=0.002$ ),

307 lowering via angiotensin II receptor antagonist associated variants decreased risk of CAD (OR

3080.11 per $10 \mathrm{mmHg}$ decrease in DBP; $95 \% \mathrm{Cl} 0.014-0.91 ; p=0.04)$, lowering via beta-blocker

309 associated variants decreased risk of CAD (OR 0.43 per $10 \mathrm{mmHg}$ decrease in DBP; $95 \% \mathrm{Cl} 0.19-$

$3101 ; p=0.05)$, and lowering via thiazide diuretic associated variants increased risk of PAD (OR 2.97

311 per $10 \mathrm{mmHg}$ decrease in DBP; 95\% $\mathrm{Cl} 1.1-8 ; \mathrm{p}=0.03)$. Only results for calcium channel blocker 
medRxiv preprint doi: https://doi.org/10.1101/2020.08.23.20180240; this version posted August 25, 2020. The copyright holder for this preprint (which was not certified by peer review) is the author/funder, who has granted medRxiv a license to display the preprint in perpetuity.

It is made available under a CC-BY-NC-ND 4.0 International license .

312 associated variants were robust in weighted-median sensitivity analyses (Supplemental Table

313 13).

314

315 DISCUSSION

This Mendelian randomization study leveraged natural genetic variation in blood

317 pressure in up to 757,601 individuals to examine the relationship between blood pressure and

318 both PAD and CAD. The principal findings were: 1) Lifetime exposure to elevated SBP, DBP, and

319 PP all increased risk of PAD and CAD; 2) Elevated SBP and DBP more strongly increased risk of

320 CAD compared to PAD; 3) PAD led to a small but significant increase in PP; 4) Based on genetic

321 proxies, the optimal antihypertensive regimens for prevention/treatment of PAD remains

322 unclear. There are several implications from the results of this study.

323 First, this study supports observational findings that elevated blood pressure is

324 associated with increased risk of PAD. Multiple observational studies have identified elevated

325 SBP and clinical diagnosis of hypertension as strong risk factors for PAD, while the relationship

326 between DBP and PAD has remained less clear (5-11,25-27). Unlike other observational

327 studies, our MR study leveraged genetic variants as instrumental variables for SBP, DBP, and PP.

328 Because genetic variants are randomly inherited by offspring from their parents, mimicking a

329 trial randomizing individuals to a lifetime of increased blood pressure, the Mendelian

330 randomization framework is less susceptible to residual environmental confounding than

331 traditional observational studies (14). The finding of our MR analysis that elevated SBP

332 increases risk of both PAD and CAD is consistent with prior studies. We also find a strong effect

333 of DBP on both PAD and CAD, clarifying discrepant findings in prior observational studies. 
medRxiv preprint doi: https://doi.org/10.1101/2020.08.23.20180240; this version posted August 25, 2020. The copyright holder for this preprint (which was not certified by peer review) is the author/funder, who has granted medRxiv a license to display the preprint in perpetuity.

It is made available under a CC-BY-NC-ND 4.0 International license .

334 Overall, the MR findings of our study are consistent with a causal relationship between blood

335 pressure traits and both PAD and CAD.

$336 \quad$ Next, we found that elevated SBP and DBP each increased risk of CAD more than PAD.

337 These findings are in contrast to a prior observational analysis that found that SBP or DBP had

338 similar effects on CAD and PAD (7). While broad recommendations for lifestyle modification

339 and treatment of ASCVD risk factors are clearly important at both the population level and

340 individual level, understanding the impact of interventions on specific ASCVD outcomes may

341 further inform treatment and prevention guidelines and discussions with patients. Particularly

342 in light of our recent finding that smoking more strongly increases risk of PAD in comparison to

343 CAD or ischemic stroke (28), this study adds further nuance to the relationship between

344 traditional ASCVD risk factors and specific ASCVD outcomes.

345 Our finding that increased pulse pressure increases PAD risk is consistent with findings

346 from multiple prior observational studies (29-32). Because increased pulse pressure is a marker

347 of increased arterial stiffness and may be caused by PAD, the observational studies

348 investigating the relationship between these traits may have been limited by the possibility of

349 reverse causality. Using bi-directional MR we were able to overcome this limitation, finding

350 elevated PP to be a risk factor for PAD, and PAD to be a risk factor for increased PP. Our

351 multivariable MR analysis of SBP and DBP suggests the effect of elevated DBP may be

352 attenuated after accounting for the genetic effect of SBP. In other words, holding diastolic

353 blood pressure constant, the effect of blood pressure on ASCVD is due to the effects of

354 increased SBP (and indirectly, increased PP). These findings lend further support for the role of 355 increased PP on PAD. 
medRxiv preprint doi: https://doi.org/10.1101/2020.08.23.20180240; this version posted August 25, 2020. The copyright holder for this preprint (which was not certified by peer review) is the author/funder, who has granted medRxiv a license to display the preprint in perpetuity.

It is made available under a CC-BY-NC-ND 4.0 International license .

Finally, we used antihypertensive drug MR to estimate the effect of $10 \mathrm{mmHg}$ lowering

357 of blood pressure by different classes of medication. In this analysis, we identified a protective

358 effect of calcium-channel blockers on risk of CAD, consistent across all sensitivity analyses.

359 Confidence intervals for other drug classes were wide, and did not exclude meaningful effects,

360 which may reflect the small number of genetic variants included in the genetic instruments for

361 each antihypertensive drug class. More robust genetic instruments may ultimately reveal

362 additional antihypertensive drug classes that robustly lower ASCVD risk. Similarly, because

363 increased SBP and DBP more strongly affected risk of CAD than PAD, the lack of effect of

364 medication-specific SBP or DBP-lowering instruments and PAD is not surprising. While small

365 beneficial genetic effects may compound over a lifetime leading to protection from ASCVD, the

366 effects of antihypertensive medications occur on a much shorter timescale. Our findings do not

367 exclude beneficial effects of potent antihypertensive medications on risk of PAD and CAD,

368 particularly given the strong causal effects of each BP trait and each ASCVD outcome.

371 (AHA/ACC) and 2017 European Society of Cardiology (ESC) PAD guidelines make strong

372 recommendations for the treatment of hypertension to prevent cardiovascular events. $(3,4)$ The

373 trials cited to support these recommendations focused on cardiovascular events broadly, or

374 differences in safety and efficacy between different antihypertensive classes, rather than PAD-

375 specific outcomes (33-41). A Cochrane Review found poor evidence for the use of

376 antihypertensive medications specifically for PAD, though recognized the large benefit of these

377 medications for prevention of cardiovascular events and mortality more broadly (42). Our MR 
medRxiv preprint doi: https://doi.org/10.1101/2020.08.23.20180240; this version posted August 25, 2020. The copyright holder for this preprint (which was not certified by peer review) is the author/funder, who has granted medRxiv a license to display the preprint in perpetuity.

It is made available under a CC-BY-NC-ND 4.0 International license .

378 study provides strong evidence consistent with a casual effect of increased blood pressure on

379 PAD. In the absence of large randomized trials of antihypertensive medications focused on

380 PAD-specific outcomes, these results add support for current guideline recommendations.

381 Further, these results may help calibrate the expected benefit that programs to treat

382 hypertension may have on the global burden of PAD.

383 This study has several potential limitations. The genetic studies of blood pressure, CAD,

384 and PAD used in our analysis were primarily composed of individuals of European ancestry.

385 Further study of BP and ASCVD genetics in diverse ancestral populations is necessary to

386 improve the generalizability of our findings. Mendelian randomization relies on a number of

387 assumptions in order for causal estimates to be valid (14). While we have employed multiple

388 MR methods and sensitivity analyses to assess for and address potential violations of these

389 assumptions, we cannot completely exclude the possibility of confounding. Future study on the

390 role of hypertension treatment in the prevention and treatment of PAD focused on PAD-specific

391 outcomes is warranted.

392 Overall, we find strong evidence consistent with a causal effect of blood pressure traits

393 on ASCVD outcomes, with a stronger effect of SBP and DBP on CAD in comparison to PAD.

394 Further study of the differential effects of traditional ASCVD risk factors on specific ASCVD

395 outcomes may help guide prevention and treatment strategies for these common diseases.

397 FUNDING:

398 This work was supported by US Department of Veterans Affairs grants IK2-CX001780

399 (Damrauer), and I01-BX003362 (Tsao/Chang). This research is based on data from the MVP, 
medRxiv preprint doi: https://doi.org/10.1101/2020.08.23.20180240; this version posted August 25, 2020. The copyright holder for this preprint (which was not certified by peer review) is the author/funder, who has granted medRxiv a license to display the preprint in perpetuity.

It is made available under a CC-BY-NC-ND 4.0 International license .

400 Office of Research and Development, Veterans Health Administration and was supported by

401 award no. MVP000. This publication does not represent the views of the Department of

402 Veterans Affairs or the United States government. This work was also supported by the

403 National Institute of Diabetes and Digestive and Kidney Diseases R01-DK101478 (Voight), and a

404 Linda Pechenik Montague Investigator Award (Voight). The Medical Research Council (MRC)

405 and the University of Bristol support the MRC Integrative Epidemiology Unit [MC_UU_12013/1,

406 MC_UU_12013/9, MC_UU_00011/1]. NMD is supported by a Norwegian Research Council

407 Grant number 295989.

408

409 DATA AVAILABILITY:

410 Summary statistics for the blood pressure genome wide association study are publicly available,

411 and may be downloaded from the NHLBI GRASP catalog

412 (https://grasp.nhlbi.nih.gov/FullResults.aspx). MVP PAD genome wide association study

413 summary statistics are available on dbGAP (Accession phs001672.v2.p1). Data on coronary

414 artery disease have been contributed by CARDIoGRAMplusC4D investigators and have been

415 downloaded from www.cardiogramplusc4d.org/data-downloads/.

417 REFERENCES:

418 1. James SL, Abate D, Abate KH, Abay SM, Abbafati C, Abbasi N, et al. Global, regional, and

419 national incidence, prevalence, and years lived with disability for 354 Diseases and

$420 \quad$ Injuries for 195 countries and territories, 1990-2017: A systematic analysis for the Global

421 Burden of Disease Study 2017. Lancet. 2018 Nov 10;1789-858. 
medRxiv preprint doi: https://doi.org/10.1101/2020.08.23.20180240; this version posted August 25, 2020. The copyright holder for this preprint (which was not certified by peer review) is the author/funder, who has granted medRxiv a license to display the preprint in perpetuity.

It is made available under a CC-BY-NC-ND 4.0 International license .

$422 \quad$ 2. Criqui MH, Aboyans V. Epidemiology of Peripheral Artery Disease. Circ Res. 2015 Apr

$423 \quad 24 ; 116(9): 1509-26$.

424 3. Gerhard-Herman MD, Gornik HL, Barrett C, Barshes NR, Corriere MA, Drachman DE, et al.

4252016 Lower Extremity Peripheral Arterial Disease Guidelines. J Am Coll Cardiol.

2017;69(11):e71-126.

427 4. Aboyans V, Ricco J-B, Bartelink M-LEL, Björck M, Brodmann M, Cohnert T, et al. 2017 ESC

$428 \quad$ Guidelines on the Diagnosis and Treatment of Peripheral Arterial Diseases, in

429 collaboration with the European Society for Vascular Surgery (ESVS): Document covering

430 atherosclerotic disease of extracranial carotid and vertebral, mesenteric, renal,. Eur

431 Heart J [Internet]. 2017 Aug 26;39(9):763-816. Available from:

432 https://doi.org/10.1093/eurheartj/ehx095

433 5. Bainton D, Sweetnam P, Baker I, Elwood P. Peripheral vascular disease: consequence for

434 survival and association with risk factors in the Speedwell prospective heart disease

435 study. Heart [Internet]. 1994 Aug 1 [cited 2019 Oct 10];72(2):128-32. Available from:

436 http://heart.bmj.com/cgi/doi/10.1136/hrt.72.2.128

437 6. Criqui $\mathrm{MH}$, Vargas V, Denenberg JO, Ho E, Allison M, Langer RD, et al. Ethnicity and

438 peripheral arterial disease: The San Diego population study. Circulation. 2005 Oct

$43925 ; 112(17): 2703-7$.

440 7. Gerald F, Housley E, Riemersma RA, Macintyre CCA, Cawood EHH, Prescott RJ, et al.

$441 \quad$ Smoking, lipids, glucose intolerance, and blood pressure as risk factors for peripheral

442 atherosclerosis compared with ischemic heart disease in the Edinburgh artery study. Am

$443 \quad$ J Epidemiol. 1992 Feb 15;135(4):331-40. 
medRxiv preprint doi: https://doi.org/10.1101/2020.08.23.20180240; this version posted August 25, 2020. The copyright holder for this preprint (which was not certified by peer review) is the author/funder, who has granted medRxiv a license to display the preprint in perpetuity.

It is made available under a CC-BY-NC-ND 4.0 International license .

444 8. Hooi JD, Kester ADM, Stoffers HEJH, Overdijk MM, Van Ree JW, Knottnerus JA. Incidence of and risk factors for asymptomatic peripheral arterial occlusive disease: A longitudinal study. Am J Epidemiol. 2001 Apr 1;153(7):666-72.

447 9. Dagenais GR, Maurice S, Robitaille NM, Gingras S, Lupien PJ. Intermittent claudication in Quebec men from 1974-1986: the Quebec Cardiovascular Study. Clin Invest Med [Internet]. 1991 Apr [cited 2019 Oct 10];14(2):93-100. Available from: http://www.ncbi.nlm.nih.gov/pubmed/2060193

10. Garg PK, Biggs ML, Carnethon M, Ix JH, Criqui MH, Britton KA, et al. Metabolic syndrome and risk of incident peripheral artery disease: The cardiovascular health study. Hypertension. 2014 Feb;63(2):413-9.

11. D.P.J. H, A. B, J.F. F, L. H, L.E. S, P.M. R, et al. Population-Based Study of Incidence, Risk Factors, Outcome, and Prognosis of Ischemic Peripheral Arterial Events: Implications for Prevention. Circulation [Internet]. 2015 [cited 2019 Oct 10];132(19):1805-15. Available 70115

12. Klarin D, Lynch J, Aragam K, Chaffin M, Assimes TL, Huang J, et al. Genome-wide association study of peripheral artery disease in the Million Veteran Program. Nat Med [Internet]. 2019 Jul 8 [cited 2019 Jul 28]; Available from: http://www.nature.com/articles/s41591-019-0492-5

464 13. Nikpay M, Goel A, Won HH, Hall LM, Willenborg C, Kanoni S, et al. A comprehensive 1000 
medRxiv preprint doi: https://doi.org/10.1101/2020.08.23.20180240; this version posted August 25, 2020. The copyright holder for this preprint (which was not certified by peer review) is the author/funder, who has granted medRxiv a license to display the preprint in perpetuity.

It is made available under a CC-BY-NC-ND 4.0 International license .

Genet. 2015;47(10):1121-30.

467 14. Davies NM, Holmes M V, Davey Smith G. Reading Mendelian randomisation studies: A guide, glossary, and checklist for clinicians. BMJ [Internet]. 2018 Jul 12 [cited 2019 Feb 15];362:k601. Available from: http://www.ncbi.nlm.nih.gov/pubmed/30002074

15. Evangelou E, Warren HR, Mosen-Ansorena D, Mifsud B, Pazoki R, Gao H, et al. Genetic analysis of over 1 million people identifies 535 new loci associated with blood pressure traits. Nat Genet. 2018 Oct 1;50(10):1412-25.

16. Bulik-Sullivan BK, Loh P-R, Finucane HK, Ripke S, Yang J, Patterson N, et al. LD Score regression distinguishes confounding from polygenicity in genome-wide association studies. Nat Genet [Internet]. 2015 Mar 2 [cited 2019 Feb 13];47(3):291-5. Available

17. Bulik-Sullivan B, Finucane HK, Anttila V, Gusev A, Day FR, Loh PR, et al. An atlas of genetic correlations across human diseases and traits. Nat Genet. 2015 Nov 1;47(11):1236-41.

18. Hemani G, Zheng J, Elsworth B, Wade KH, Haberland V, Baird D, et al. The MR-base platform supports systematic causal inference across the human phenome. Elife. 2018;

19. Shim H, Chasman DI, Smith JD, Mora S, Ridker PM, Nickerson DA, et al. A multivariate genome-wide association analysis of $10 \mathrm{LDL}$ subfractions, and their response to statin treatment, in 1868 Caucasians. PLoS One. 2015;

484 20. Palmer TM, Lawlor DA, Harbord RM, Sheehan NA, Tobias JH, Timpson NJ, et al. Using multiple genetic variants as instrumental variables for modifiable risk factors. Stat 
medRxiv preprint doi: https://doi.org/10.1101/2020.08.23.20180240; this version posted August 25, 2020. The copyright holder for this preprint (which was not certified by peer review) is the author/funder, who has granted medRxiv a license to display the preprint in perpetuity.

It is made available under a CC-BY-NC-ND 4.0 International license .

488 21. Bowden J, Davey Smith G, Haycock PC, Burgess S. Consistent Estimation in Mendelian

Randomization with Some Invalid Instruments Using a Weighted Median Estimator.

Genet Epidemiol [Internet]. 2016 May [cited 2019 Feb 28];40(4):304-14. Available from:

http://www.ncbi.nlm.nih.gov/pubmed/27061298

492 22. Sanderson E, Davey Smith G, Windmeijer F, Bowden J. An examination of multivariable

Mendelian randomization in the single-sample and two-sample summary data settings.

Int J Epidemiol. 2019 Jun 1;48(3):713-27.

495 23. Gill D, Georgakis MK, Koskeridis F, Jiang L, Feng Q, Wei W-Q, et al. Use of Genetic

Variants Related to Antihypertensive Drugs to Inform on Efficacy and Side Effects.

Circulation. 2019 Jul 23;140(4):270-9.

24. Walker VM, Kehoe PG, Martin RM, Davies NM. Repurposing antihypertensive drugs for the prevention of Alzheimer's disease: a Mendelian randomization study. Int J Epidemiol. 2019 Jul 23;

25. Meijer WT, Grobbee DE, Hunink MGM, Hofman A, Hoes AW. Determinants of peripheral arterial disease in the elderly: The Rotterdam Study. Arch Intern Med. 2000 Oct 23;160(19):2934-8.

26. Newman AB, Siscovick DS, Manolio TA, Polak J, Fried LP, Borhani NO, et al. Ankle-arm index as a marker of atherosclerosis in the cardiovascular health study. Circulation. 1993;88(3):837-45.

27. McGee DL. Update on Some Epidemiologic Features of Intermittent Claudication: The Framingham Study. J Am Geriatr Soc. 1985;33(1):13-8. 
medRxiv preprint doi: https://doi.org/10.1101/2020.08.23.20180240; this version posted August 25, 2020. The copyright holder for this preprint (which was not certified by peer review) is the author/funder, who has granted medRxiv a license to display the preprint in perpetuity.

It is made available under a CC-BY-NC-ND 4.0 International license .

Smoking and Risk of Atherosclerotic Cardiovascular Diseases: A Mendelian

Randomization Study. medRxiv. 2020 Apr 8;2020.04.07.20053447.

512 29. Mao Y, Huang Y, Yu H, Xu P, Yu G, Yu J, et al. Incidence of peripheral arterial disease and

its association with pulse pressure: A prospective cohort study. Front Endocrinol

514

(Lausanne). 2017 Nov 24;8(NOV).

515

30. Zhan Y, Yu J, Chen R, Sun Y, Fu Y, Zhang L, et al. Prevalence of low ankle brachial index

and its association with pulse pressure in an elderly Chinese population: a cross-sectional

study. J Epidemiol [Internet]. 2012 [cited 2019 Oct 10];22(5):454-61. Available from:

http://www.ncbi.nlm.nih.gov/pubmed/22813646

31. Korhonen $\mathrm{P}$, Kautiainen $\mathrm{H}$, Aarnio P. Pulse pressure and subclinical peripheral artery

disease. J Hum Hypertens [Internet]. 2014 Apr [cited 2019 Oct 10];28(4):242-5. Available

from: http://www.ncbi.nlm.nih.gov/pubmed/24132137

32. Kiuchi S, Hisatake S, Watanabe I, Toda M, Kabuki T, Oka T, et al. Pulse Pressure and

Upstroke Time Are Useful Parameters for the Diagnosis of Peripheral Artery Disease in

Oct 10];7(5):161-6. Available from: http://www.ncbi.nlm.nih.gov/pubmed/28197286

33. Ostergren J, Sleight P, Dagenais G, Danisa K, Bosch J, Qilong Y, et al. Impact of ramipril in

[Internet]. 2004 Jan [cited 2019 Oct 10];25(1):17-24. Available from:

34. Yusuf S. Effects of an angiotensin-converting-enzyme inhibitor, ramipril, on cardiovascular events in high-risk patients. N Engl J Med. 2000 Jan 20;342(3):145-53. 
medRxiv preprint doi: https://doi.org/10.1101/2020.08.23.20180240; this version posted August 25, 2020. The copyright holder for this preprint (which was not certified by peer review) is the author/funder, who has granted medRxiv a license to display the preprint in perpetuity.

It is made available under a CC-BY-NC-ND 4.0 International license .

532 35. Yusuf S, Teo KK, Pogue J, Dyal L, Copland I, Schumacher H, et al. Telmisartan, ramipril, or both in patients at high risk for vascular events. N Engl J Med. 2008 Apr 10;358(15):154759.

36. Bavry AA, Anderson RD, Gong Y, Denardo SJ, Cooper-Dehoff RM, Handberg EM, et al. artery disease: findings from the INternational VErapamil-SR/Trandolapril STudy. Hypertens (Dallas, Tex 1979) [Internet]. 2010 Jan [cited 2019 Oct 10];55(1):48-53. Available from: http://www.ncbi.nlm.nih.gov/pubmed/19996066

37. Zanchetti A, Julius S, Kjeldsen S, Mclnnes GT, Hua T, Weber M, et al. Outcomes in subgroups of hypertensive patients treated with regimens based on valsartan and amlodipine: An analysis of findings from the VALUE trial. J Hypertens [Internet]. 2006 Nov [cited 2019 Oct 10];24(11):2163-8. Available from:

38. Diehm C, Pittrow D, Lawall H. Effect of nebivolol vs. hydrochlorothiazide on the walking capacity in hypertensive patients with intermittent claudication. J Hypertens [Internet]. 2011 Jul [cited 2019 Oct 10];29(7):1448-56. Available from: http://www.ncbi.nlm.nih.gov/pubmed/21602713

39. Espinola-Klein C, Weisser G, Jagodzinski A, Savvidis S, Warnholtz A, Ostad M-A, et al. $\beta$ the nebivolol or metoprolol in arterial occlusive disease trial. Hypertens (Dallas, Tex 1979) [Internet]. 2011 Aug [cited 2019 Oct 10];58(2):148-54. Available from: 
medRxiv preprint doi: https://doi.org/10.1101/2020.08.23.20180240; this version posted August 25, 2020. The copyright holder for this preprint (which was not certified by peer review) is the author/funder, who has granted medRxiv a license to display the preprint in perpetuity. It is made available under a CC-BY-NC-ND 4.0 International license.

554 40. Paravastu SCV, Mendonca DA, Da Silva A. Beta blockers for peripheral arterial disease. Cochrane database Syst Rev [Internet]. 2013 Sep 11 [cited 2019 Oct 10];(9):CD005508.

Available from: http://www.ncbi.nlm.nih.gov/pubmed/24027118

557 41. Group TAO and C for the ACR, Coordinators TAO and, Antihypertensive T, Treatment L. Major Outcomes in High-Risk Hypertensive Patients Randomized to AngiotensinConverting Enzyme Inhibitor or Calcium Channel Blocker vs Diuretic. JAMA J Am Med Assoc [Internet]. 2002 [cited 2019 Oct 10];288(23):2981-97. Available from: http://www.ncbi.nlm.nih.gov/pubmed/12479763

562 42. Lane DA, Lip GYH. Treatment of hypertension in peripheral arterial disease. Vol. 2013, 563 Cochrane Database of Systematic Reviews. John Wiley and Sons Ltd; 2013. 
Figure 1: Effect of Blood Pressure Traits on ASCVD Outcomes

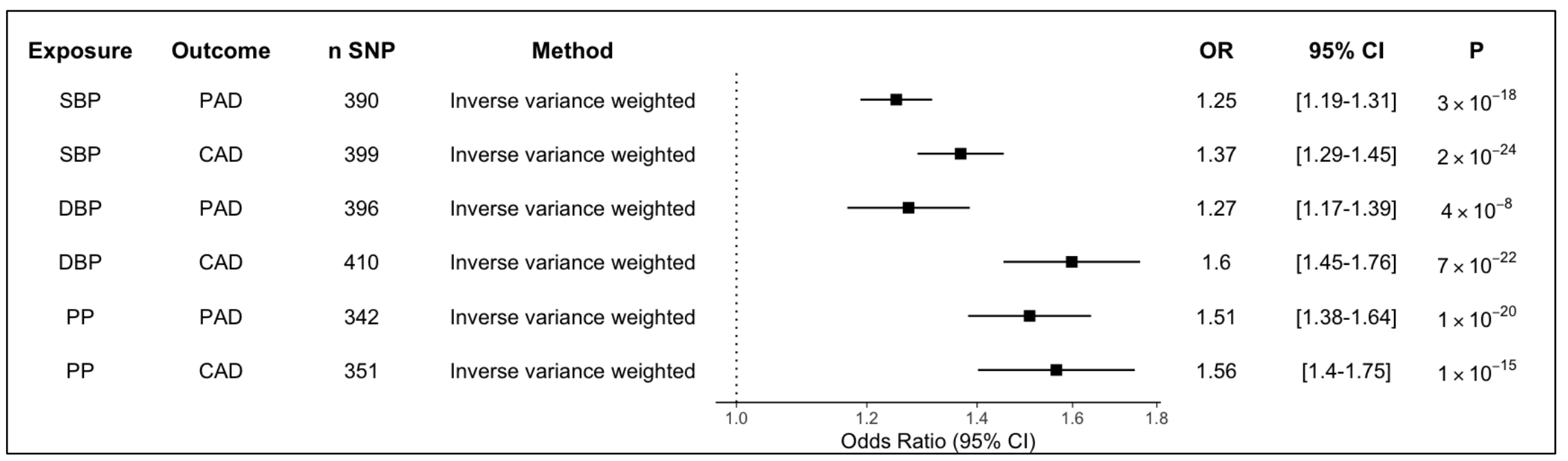

In inverse variance weighted Mendelian randomization analyses, elevations in each blood pressure trait increased risk of both

coronary and peripheral artery disease. Results scaled to reflect odds of outcome per $10 \mathrm{mmHg}$ increase in blood pressure. $\mathrm{n}$ SNP $=$

569 number of single nucleotide polymorphisms in the exposure instrument; $\mathrm{OR}=$ odds ratio; $95 \% \mathrm{Cl}=95 \%$ confidence interval; $\mathrm{P}=\mathrm{p}$ -

570 value SBP = Systolic blood pressure; $\mathrm{DBP}=$ Diastolic blood pressure; $\mathrm{PP}=$ Pulse pressure PAD = Peripheral artery disease; $\mathrm{CAD}=$

571 coronary artery disease. 
Figure 2: Effect of ASCVD Traits on Blood Pressure

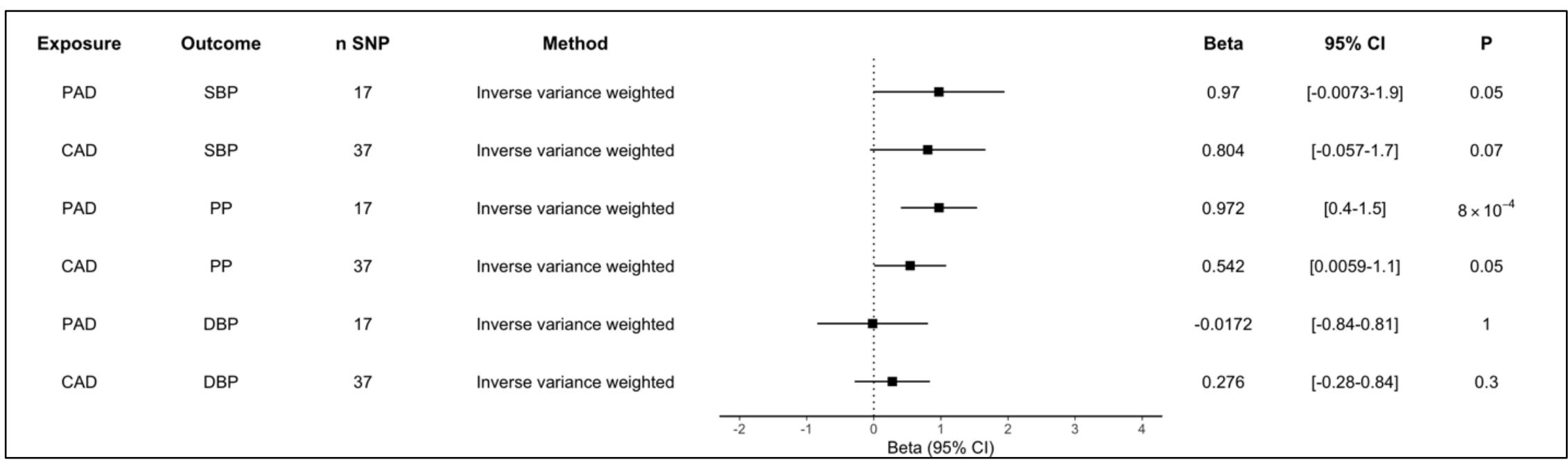

In inverse variance weighted Mendelian randomization analyses, both peripheral artery disease and coronary artery disease

576 increased pulse pressure. Results reflect increase in blood pressure (mmHg per 1 log-odds unit increase in risk of the exposure). $n$

577 SNP = number of single nucleotide polymorphisms in the exposure instrument; $\mathrm{OR}=$ odds ratio; $95 \% \mathrm{Cl}=95 \%$ confidence interval; $\mathrm{P}$

$578=\mathrm{p}$-value SBP = Systolic blood pressure DBP = Diastolic blood pressure $; \mathrm{PP}=$ Pulse pressure PAD = Peripheral artery disease $;$ CAD =

579 coronary artery disease. 
$581 \quad$ Figure 3: Mendelian Randomization Estimates of the Effect of Systolic Blood Pressure Lowering Through Antihypertensive

582 Medication-associated Genetic Variants

\begin{tabular}{|c|c|c|c|c|c|c|c|c|}
\hline Exposure & Outcome & n SNP & Method & & & OR & $95 \% \mathrm{Cl}$ & $\mathbf{P}$ \\
\hline Calcium-channel blocker & PAD & 24 & Inverse variance weighted & $\rightarrow$ & & 0.976 & {$[0.811-1.17]$} & 0.8 \\
\hline Calcium-channel blocker & CAD & 24 & Inverse variance weighted & - & & 0.685 & {$[0.586-0.801]$} & $2 \times 10^{-6}$ \\
\hline Beta-blocker & PAD & 6 & Inverse variance weighted & 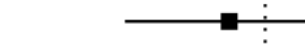 & & 0.898 & {$[0.656-1.23]$} & 0.5 \\
\hline Beta-blocker & CAD & 6 & Inverse variance weighted & & & 0.589 & [0.442-0.784] & $3 \times 10^{-4}$ \\
\hline $\mathrm{ACEi}$ & PAD & 1 & Wald ratio & & & 0.662 & {$[0.318-1.38]$} & 0.3 \\
\hline \multirow[t]{2}{*}{ ACEi } & CAD & 1 & Wald ratio & & & 0.821 & {$[0.418-1.61]$} & 0.6 \\
\hline & & & & $\begin{array}{ll}0.5 & 1.0 \\
\text { Odds Ratio } & (95 \% \mathrm{Cl})\end{array}$ & 1.5 & & & \\
\hline
\end{tabular}

584 Results scaled to reflect odds of outcome per $10 \mathrm{mmHg}$ decrease in blood pressure. $\mathrm{n}$ SNP $=$ number of single nucleotide

585 polymorphisms in the exposure instrument; $\mathrm{OR}=$ odds ratio; $95 \% \mathrm{Cl}=95 \%$ confidence interval; $\mathrm{P}=\mathrm{p}$-value SBP = Systolic blood

586 pressure; $\mathrm{DBP}=$ Diastolic blood pressure; $\mathrm{PP}=$ Pulse pressure; $\mathrm{PAD}=$ Peripheral artery disease; $\mathrm{CAD}=$ coronary artery disease. 
588 Supplemental Figure 1: Genetic Correlation Between Blood Pressure Traits

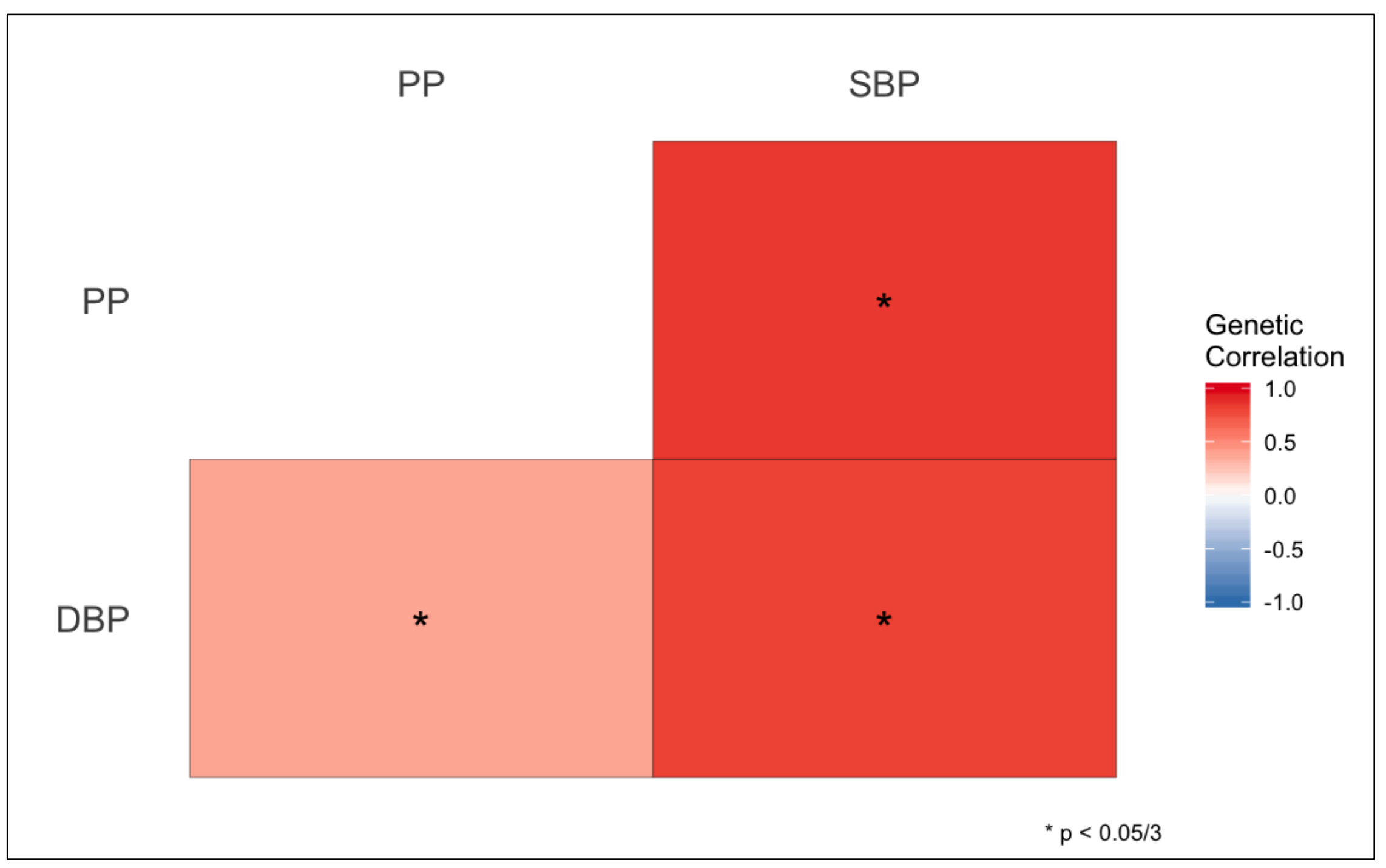


591 Supplemental Figure 2: Genetic Correlation Between Blood Pressure and ASCVD Traits

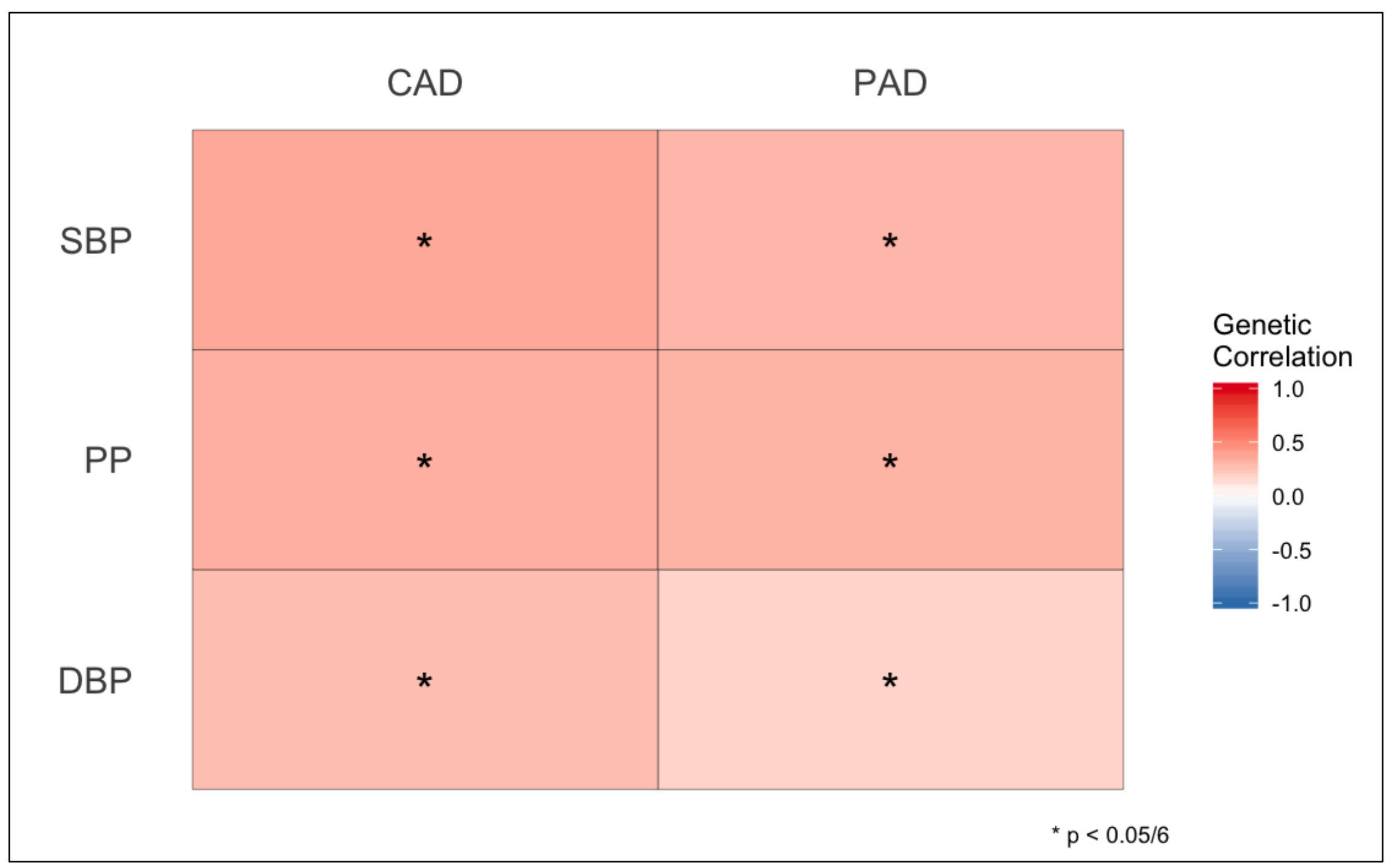

